\title{
Walking at Midnight: Women and Danger on Delhi's Streets
}

\author{
Swati Arora \\ University of the Western Cape, Cape Town, South Africa
}

\begin{abstract}
I discuss the walking practice of Delhi-based artist Mallika Taneja in the context of its engagement with, and intervention in, the contemporary conversations on sexualised violence, gender, space and mobility in India. Taneja's work is part of a variety of feminist activism to take place in India since the horrific gang rape of Jyoti Singh in Delhi in December 2012. Taneja organises regular midnight walks in various parts of the city, which are advertised via social media. This essay explores the significance of walking as a pedagogical tool to understand the relationship between gender, city, space and mobility in Delhi. When conversations on sexualized violence are accelerating in the wake of \#MeToo, I examine the contours of embodied knowledge practices enabled by collective walking by women at midnight. I discuss how walking-based methodologies allow for a learning process that is lived, somatic, and personal and which is rooted in specific spatial contexts based on listening and care. Using an intersectional perspective that pays close attention to the role of region, class, caste, sexuality and ethnicity (Mohanty, 2013), this essay is also a prompt against a unified theory of gender, safety, and mobility.
\end{abstract}

\section{Key Words}

Delhi; gender; danger; midnight; respectability; Mallika Taneja 
On 16 December 2018, at around 11:30 pm, a group of about 25 women gathered in front of PVR Anupam, an upmarket cinema in Saket in the southern part of Delhi. Strangers to each other at first, quiet whispers and awkward greetings changed to comfortable conversations within the next 30 minutes. Wrapped in assorted shades of woollens, they had come to participate in the night walk organised by the Delhi-based artist Mallika Taneja. The WhatsApp group created for the event enabled coordination of travel: most of the participants shared Uber rides with each other, a few had brought their friends along for company; hardly anyone came by themselves. We were to begin the walk at midnight and continue for approximately two hours, beginning in Saket and ending at Munirka bus stop. ${ }^{i}$ The route covered on foot was to imitate that of the bus that Jyoti Singh boarded on the same date six years ago. After watching a film with her friend at PVR Anupam, Jyoti Singh was gang-raped by six men in the moving bus and later died of her wounds.

This essay explores the significance of walking as a pedagogical tool to understand the relationship between gender, city, space and mobility in Delhi. When conversations on sexualized violence are accelerating in the wake of \#MeToo, I examine the contours of embodied knowledge practices enabled by collective walking by women at midnight. I discuss how walking-based methodologies allow for a learning process that is lived, somatic and personal, and which is rooted in specific spatial contexts based on listening and care. Using an intersectional perspective that pays close attention to the role of region, class, caste, sexuality and ethnicity (Mohanty, 2013), this essay is also a prompt against a unified theory of gender, safety and mobility.

Taneja began organising night walks in Delhi three years ago and today, the initiative has acquired the shape of a collective with a few core members. Known as 'Women Walk at Midnight,' the handle is steadily acquiring popularity and followers on social media as well as expanding to other cities in India. ${ }^{\text {ii }}$ As of June 2019, midnight walking events have been organised in Bangalore and Lucknow. Following their commitment to democratise public spaces, the collective encourages and invites different women to lead walks in different areas of the city, which are advertised mostly in English through Facebook. The walk on 16 December 2018 was led by Neha Singh, a Delhi-based journalist specialising in gender and human rights.

This walking practice follows after Phadke, Khan and Ranade (2011), who encourage women to loiter in dangerous streets and take risks in order to experience pleasure. The authors point out the pejorative connotations of 'loitering' as it is marked by masculine adjectives when translated in Hindi-lukka, lafanga, vella, tapori, bekaar-implying that the pleasures of the public street space, neither admirable nor acceptable, are reserved for men only. The carefree abandon associated with crowding and chatting at street corners or boarding the night bus is discouraged for women because of the dangerous implications it has for their safety.

But since there is no singular category of 'woman,' as it is always experienced as intersecting with religion, class, caste, ethnicity and sexuality, the question arises: who finds the city streets 'dangerous' at night? Of the women who had assembled that night, all of them were able-bodied, middle-class women, mostly dressed in jeans and jackets. A few were wearing long kurtas. Our demeanour was undoubtedly reflective of our class backgrounds. The women belonged to the age group of 20-40; only one of them was a teenager who had accompanied her mother. All of them, except one, had material advantages that made their participation in the midnight walk possible: 1 ) they lived in the upmarket south part of Delhi, and 2) had the resources to either hire or share a cab ride. Only one of the participants lived in Rajouri Garden, west Delhi, and had gone through a lot of trouble arranging travel for 
this event. Another midnight walk was scheduled to take place on 12 January 2019 in Tilak Nagar, in the west part of Delhi, but was cancelled last minute due to lack of participants and the resulting safety concerns that arose from insufficient numbers of walkers.

The lack of enough participants for the Tilak Nagar walk is not incidental, and points to the tensions not just within Taneja's spatial practice, but within a general presumption about walking art as an inherently democratic practice (Arora, in press). Sharanya Murali (2017) asks us to pay attention to the "postcolonial body/site dialectic" (p. 86) as it is not just about the body who walks that determines the coordinates and relationalities of walking, but also the physical site in which it is undertaken. South Delhi is an affluent part of Delhi that houses a middle-class with a high cultural and financial capital. This privilege also translates into networking opportunities between similar people as a result of social media connections: Taneja's use of Facebook and Instagram to send out invitations for her walk results in inviting participants that are similar to her class, caste, ethnic, religious and regional background. West Delhi was developed post-Partition, in 1947, as refugee colonies were created to house the incoming Hindu refugees from Pakistan; it is neither the most affluent nor considered the most progressive part of Delhi (Chatterjee, 2015). It is further out from South Delhi where Taneja's audience and participants live. Either due to the tyranny of distance or the cold winter nights, the midnight walk in Tilak Nagar could not attract enough women as participants and so was postponed to 25 January. Even then, only four women turned up. The embodied experiences of the 16 December walk-from Saket to Munirka-were inflected through the relative freedoms and privileges that the residents of the south part of Delhi afford. A homogenous narrative of freedom or mobility does not exist.

Phadke (2013), reflecting on the "realities of layered exclusion and multiple marginalizations" (p. 52), writes that violence against women in public is located alongside "violence against the poor, Muslims, dalits, hawkers, sex workers and bar dancers" (p. 52). The middleclass, upper-caste woman, with her cultural, social, symbolic and material capital, is considered respectable and warrants protection, lest her morality is corrupted by the 'other' bodies on the street. Tellingly, on the night of the walking event, a police van with an inspector and two constables stopped to inquire about our motives just as the group had started walking and followed us until the end. Lack of male company and the sheer size of the group had not gone unnoticed. Taneja and Dixit reassured the officers that the group did not need any help and was just taking a walk but, predictably, that did not help. We were also approached by auto-rickshaws whose drivers were shocked to see that our group was choosing to walk on a cold December night, and was refusing to hire a ride. The presence of the auto drivers did not feel threatening; their offers of a ride mostly seemed like a desire to make profits. A group of middle-class women walking past midnight was surely not a usual sight and the passers-by did not leave any opportunity to intrude or pass comments.

We walked until $2 \mathrm{am}$. The meditative experience of feeling the calm quietness on the streets while being enveloped by dark skies is something that I had never experienced in Delhi before. I could notice ordinary yet striking things: the street signs, the presence or the lack of street lights, posters and banners on the walls. The irony of the slogans painted on the walls was not missed by anyone - Beti Bachao, Beti Padhao (Save the Daughter, Educate the Daughter). In the run-up to the national elections in May 2019, women's rights were at the top of the ruling Bharatiya Janata Party's agenda. The reality, however, is quite different.

As we concluded the walk at the bus stop and assembled for a discussion, the police approached us again, expressing safety concerns. "Where are you all from? How will you go home? When will you go home?" asked the inspector, looking suspicious. This time, the group had acquired more confidence, having completed the journey. Some of the women 
politely responded to the questions and resumed the group discussion. Not convinced about our motives, the police van refused to leave us alone, and the officers stayed around while the members of our group shared their thoughts and feelings on the walk. Meanwhile, women police officers were called for, lest physical force was needed to dissipate us. We watched with a calm demeanour and continued talking to teach other. Giggles ensued when Taneja decided to put the officers to good use by requesting them to take a photograph of the group.

As a pedagogical tool, walking as a form of protest and public art, and not as a mode of transportation, offers an embodied way of experiencing and witnessing the divisions in India's social fabric. The urban outdoor, especially at night time, is permanently reserved for the country's 'excess' - financially poor men and women, Dalits, sex workers, homeless people. Class and caste inequalities are spatially configured across Delhi when the middle classes collude with the state to relegate marginalised socio-economic groups to the peripheries through exclusionary forms of citizenship like gated communities. Changing middle-class consumption practices due to economic liberalisation has resulted in a 'politics of forgetting' the marginalised groups of men and women who are deemed undesirable and 'dangerous' (Fernandes, 2004).

When middle-class women attempt to access public spaces as an act of defiance during a performance event, the radicality of the initiative is already defined-and bound-by the temporary nature of that desire. After two hours, the participants return home to their comfortable beds. But the homeless poor and the sex workers have no such hope. This mode of 'occupying' the urban, construed as a radical and liberatory act, overlooks the concerns of minority women who belong to different castes, religion and socio-economic backgrounds, and who inhabit public spaces in very different ways - either out of 'compulsions of economics' or due to dire infrastructural gaps like lack of toilets (Chatterjee, 2011, p. 170).

The iconography of the midnight walking event shared on their social media pages evokes a classist perception of freedom and mobility as well. With the re-election of a Hindu right-wing leader Narendra Modi as the Prime Minister in May 2019, the ruling Bharatiya Janata Party is normalising Islamophobia and anti-Dalit violence through 'saffronisation of the public sphere' (Anderson \& Jaffrelot, 2018). The proliferation of an aggressive and insular Hindutva ideology — one which borders on fascism, violates women's bodies in order to define itself, demoralises minority communities, and destabilises resistance-poses a serious threat to the future of Indian democracy. iii

In the light of such volatile developments, the intent to roam the streets of Delhi at midnight dares to defy these imposed rules. Collective walking allowed us all to bask in the darkness and the quiet, to dream and to linger. It created a space in time to allow for the work of embodied thinking which happens as the clutter of the mind is put to rest. Feeling safe in each other's company consolidated the feeling that a male companion is not required for women's protection. It laid down a possible blueprint for a potential future when allwomen midnight walking groups become a norm until they are not an unusual sight anymore. Jyoti Singh dared to flout the patriarchal rules of public spaces by choosing to be out on the streets at night with a male friend and was punished for doing so. Collective walking events attempt to speak back to the sexual violence that is meted out to women like her who refuse to limit their dreams and desires.

Walking collectively also mobilises activism in ways that other forms of protest cannot. The midnight walking event I participated in hints at the "political potential of a walking that mobilises social relationships" (Heddon \& Turner, 2012, p. 236). During the two hours of the walk, I managed to have lengthy conversations with three other women on diverse topics. We talked about the perils of being a freelance artist in India, the turmoil of moving 
countries when you are a single woman, and reminisced about college days since my fellow walker happened to come from my undergraduate college. There was a tangible feeling of seeking support through another's company as the group marched forward. The discussion at the end of the walk was very heartening. There was a sense of being overwhelmed by the opportunity to walk on Delhi's streets at this time of the night. The sheer sense of victory felt by the group was palpable, of having survived the night without being molested. The historical significance of the date also resonated very profoundly. One of the walkers was a student at the nearby Jawaharlal Nehru University and had participated in the walk organised by the university in the aftermath of Jyoti Singh's death in December 2012.

Walking with a group of women who had chosen to come out at this time of the night also raises questions about work and leisure. When the clock strikes midnight, it signals towards a designated time for resting the tired bodies that have toiled during the day. Choosing to delay or compromise sleep and rest also points to the relatively privileged position of the participating women who could come out at midnight. They either had no care responsibilities or had paid a lower-class, lower-caste woman to take on these duties. Activism and revolution, entangled in caste and class structures, demand time and effort that is not available to everyone.

Taneja's political optimism was very evident, and her desperation to share it with her comrades even more so. But she is not naïve about her inability to change the external structures of governance that inhibit the mobility of women like her. The resistance her practice invokes is very personal: every individual takes home a different sense of victory. Her walking practice enables middle-class women to leave the tag of respectability at home and partake in the dangers of the night, creating collective memories through repeated acts until it becomes normal. It displays potential for building solidarities through sharing: physical proximity and aural presence of companions in the dark. Women who were strangers to each other, met at a designated spot, at an unusual time, and exchanged notes about life, art, fear and vulnerability. Huddle: in these tumultuous times, maybe all we have is each other's company.

\section{References}

Anderson, E., and Jaffrelot, C. (2018). Hindu nationalism and the 'Saffronisation of the Public Sphere': An interview with Christopher Jaffrelot. Contemporary South Asia, 26(4), 464-482. https://doi.org/10.1080/09584935.2018.1545009

Arora, S. (in press). Walk(ing) in India and South Africa: Notes towards a transnational politics of solidarity. South African Theatre Journal.

Chatterjee, D. (2011). Dalit rights/Human rights. Jaipur: Rawat Publications.

Chatterjee, P. (2015). Managing urban transformations of refugee settlements in west Delhi from camps to nagars: The story of Moti Nagar and Kirti Nagar. Creative Space, 2(2), 183-208. doi:10.15415/cs.2015.22011

Fernandes, L. (2004). The politics of forgetting: Class politics, state power and the restructuring of urban space in India. Urban Studies, 41(12), 2415-2430. doi:10.1080/00420980412331297609

Heddon, D. and Turner, C. (2012). Walking women: Shifting the tales and scales of mobility. Contemporary Theatre Review, 22(2), 224-36. https://doi.org/10.1080/10486801.2012.666741 
Mohanty, C.T. (2013). 'Under Western Eyes' revisited: Feminist solidarity through anticapitalist struggles. In C. R. McCann \& S. K. Kim (Eds.), Feminist Theory Reader (pp. 536-552). New York, NY: Routledge.

Murali, S. (2017). A manifesto to decolonise walking. Performance Research, 22(3), 85-88. http://dx.doi.org/10.17613/M6TF83

Phadke, S. (2013). Unfriendly bodies, hostile cities. Economic and Political Weekly, 48(39), 50-59. Retrieved from https://www.jstor.org/stable/23528480

Phadke, S., Khan, S., \& Ranade, S. (2011). Why loiter?: Women and risk on Mumbai streets. Delhi: Penguin Books.

Swati Arora is a Mellon Foundation-funded Postdoctoral Fellow in Women's and Gender Studies, UWC. Informed by feminist theory, critical urban studies and post/de-colonial theory, her research explores gendered violence, street-art and performance in India. Swati coconvenes the IFTR's Performance in Public Spaces group, and is a fellow of the IATC.

\footnotetext{
i Youth Ki Awaaz, "Women Walk the Streets of Delhi in Memory of 'Nirbhaya". Available online at https://www.youtube.com/watch?v=BDhQ45nNZDM

ii Link to the Instagram handle of Women Walk at Midnight: https://www.instagram.com/wewalkatmidnight/

iii Love-jihad is a campaign run by Hindu right-wing groups against what they say is a Muslim conspiracy to convert Hindu girls to Islam by feigning love. 'Anti-Romeo' squad was launched in March 2017 by the newly appointment Chief Minister of Uttar Pradesh to 'protect' women from suspected youth who harassed them. The current government has banned the consumption of beef (the cow is considered a sacred animal by Hindus), and failure to abide by this law has led to lynching of Muslims and Dalits by Hindu mobs.
} 